\title{
Challenges and opportunities
}

For discussion

Dedicated to the bright memory of professor Dr AA. Zhuchenko, the initiator of organic agriculture in Russia

\section{GENERAL POSITION OF ORGANIC AGRICULTURE IN WESTERN EUROPE: CONCEPT, PRACTICAL ASPECTS AND GLOBAL PROSPECTS}

\section{J.D. VAN MANSVELT ${ }^{1}$, S.K. TEMIRBEKOVA ${ }^{2}$}

\author{
${ }^{1}$ Down 2Earth foundation, p/a Hageweer 43, NL 1151 ER, Broek in Waterland, The Netherlands, e-mail \\ jandiek@vanmansvelt.nl (corresponding author); \\ 2 All-Russian Research Institute of Phytopathology, Federal Agency of Scientific Organizations, 5, ul. Institute, pos. \\ Bol'shie Vyazemy, Odintsovskii Region, Moscow Province, 143050 Russia, e-mail sul20@yandex.ru (corresponding \\ author)
}

ORCID: Temirbekova S.K. orcid.org/0000-0001-9824-6364

The authors declare no conflict of interests

Received March 10, 2017

\section{Abstract}

Here we present a deep analysis of agriculture in Western Europe, the provisions and principles of its ecological direction. It is noted that Germany and France are the leaders of the EU countries for the production of environmentally friendly products. Organic agriculture is viewed as a holistic ecosystem, where each change affects a complex of complex interrelations, which include both genetic species diversity of crops and livestock. In natural ecosystems, the synthesis, decomposition and consumption of nutrients with the participation of green plants (photosynthesis), insects, animals (herbivores and predators), and microorganisms are constantly occurring. The basis of ecological agriculture and organic farming is healthy soil and fertility soil. Fertile and biologically active soil will provide plants with a sufficient number of nutrients for optimal growth and development, minimize possible damage from diseases, pests and weeds. Improvement of soil ecosystems guarantees the best yields, it is a kind of circular model of long-term planning. The combination of plant growing and animal husbandry in the ecosystem is noted. It represents the alternation of processes of synthesis and decomposition, which is accompanied by an increase in the quality of life in soils, plants, animals, in the life of the entire agro-ecosystem. Organic fertilizers create favorable conditions for inclusion in the agro-ecosystem elements that accelerate life processes in the soil and thereby ensure the growth of plants. A special role is assigned to the rotation in ecological agriculture. It promotes the cultivation of legumes - the main suppliers of nitrogen in the agro-ecosystem. It is the most important means of protection against pests and diseases, and it interferes with a long monoculture. It is a mean of regulating weed vegetation. Inclusion of perennial forage crops in crop rotation helps a farmer prevent the extreme growth of each species of weeds to a dangerous level. The importance of manure and slurry for the ecosystem of the soil, as well as that of the straw litter for animals, was noted. Data on hunger and obesity in some countries are given. Integrated agriculture is also considered as an alternative to traditional agriculture. But solving environmental pollution problems by integrated agriculture is less effective. In the EU countries, financial support is provided to organic farming. By 2020, the world market for organic products is projected to be 200-250 billion dollars, with the potential of the Russian market of 700 billion rubles. That is, Russia can account for $10-15 \%$ of the market. In Russia, there is a demand for organic food. Organic agriculture contributes not only to the production of healthy food, but also to the preservation of the habitat, biodiversity and respect for wild and agricultural animals.

Keywords: organic products, organic farming, agro-ecosystems, soil fertility, healthy soil, natural fertilizers, legumes, crop rotation, integrated agrotechnology, biodiversity

Agro-ecological farming systems, like organic-, permaculture and biodynamic-agriculture (or organobiological) agriculture, are mainly based on organic fertilizers (manure, composts, siderates), nitrogen fixation in legumes, crop rotation and integrated plant protection (by use of biomethods and varieties resistant 
to pests, weeds and diseases), control of crop quality and optimal balance of nutrients along with a decrease in energy consumption per unit of final product. Resulted products are considered organic eco-friendly food [1-5]. In 2011, the world environmentally friendly products exceeded $45 \mathrm{bln} €$, including $21 \mathrm{bln} €$ in the US and $21.5 \mathrm{bln} €$ in Europe. The leaders of European market are Germany (6.6 bln $€)$ and France (3.8 bln $€$ ). The countries with the highest consumption per capita of environmentally friendly products are Switzerland and Denmark (more than $160 €$ per year). The largest number of environmentally friendly food producers is located in India, Uganda, Mexico and Tanzania [6].

Organic farming: general principles. Plant growing, as a primary production system, is peculiar in its dependence on local natural conditions. Agriculture as a whole is an art of providing for necessary prerequisites to use the entire self-organizing bioecological potential of soil-plant-animal systems and to enhance the efficiency of naturally occurred processes. In fact, holistic living agro-ecosystems are here the essential mean and productive forces the basis of which is the soil.

The roots of plants are obviously hidden from our direct observation as they grow into the darkness of the soil. That plain fact hampers our immediate understanding of what they actually do, and how. Plant growth research in glassware is a helpful tool, but it creates a crucial artefact: in the laboratory as well as in our minds. We apply 'pure' chemicals that we presume to be plant nutrients, to find out which of them are needed. But using this presumption and its experimental setting, we can only find that plants indeed use (and thus 'need') soluble nutrients, which they absorb with sets of identical roots, in a uniform environment.

In this paper we choose for the concept wherein plants grow in soils that are seen as ecosystems or, in other words, in 'living' soils. Amelioration of the farms' soils is in that concept the prime goal of the farmer, with the overall objective to have ever better harvests by ongoing improvement of precisely those soils. These soils then again are seen within the farms biotope as a whole, in the farm's landscape, which includes all environmental compartments [2].

Soil is alpha and omega in agriculture. Plant growth depends on soil processes, and plant organic residues are decomposed in soil up to nutrients for other plants [7-10]. So soil health and fertility must be preserved and improved. Soil is a natural ecosystem with the greatest variety of micro and macro bionts $[2,7]$, i.e. fungi, algae, bacteria (including those decomposing mycelium and chitin), earthworms, beetles etc., which restore soil fertility. Soil biota also contributes to water retention in the biologically active plow layer, optimal growth and increase in plant resistance to diseases [8, 10]. This is a whole process that still is largely unknown in detail. Physicochemical properties (particle size and capillarity, etc.) are another important factor of soil quality [10]. The root systems multi-functionality invites us to provide them with a soil ecosystem wherein they can find what they need when they need it. And if the soil lacks structure, water reserves, bacteria, mycorrhiza, minerals or whatever, the challenge is to start growing crops that provide for what is missing. Apart from roots for feeding, plants have roots specialised in water uptake, in weathering rocks and in stabilising the plants' stems vertical uprising. And always, dying roots leave organic matter in the soils they have grown in: energy-food for the ecosystem. Healthy soil allows for uniform spread and deep penetration of plant roots. The more small rootlets and root hairs are in the plant root system, the healthier the soil and soil organisms are. Unbranched roots often indicate a weak biological activity of the soil due to densification and lack of air. In legumes, roots are indicative of soil air level. At enough aeration, in nodules, which appear on roots, 
$\mathrm{N}_{2}$-fixign bacteria can transform atmospheric nitrogen into fixed nitrogen usable by plants [9].

Measures to keep up natural balance in the agro-ecosystem should be consistent with the concept of organic agriculture, otherwise the result be the opposite. Some scientists assert that the introduction of mineral fertilizers reduces the activity of soil bacteria and nitrogen fixation in legumes [11, 12] and shifts ecological balance to increased plant sensitivity to diseases and pests. The latter, in turn, requires more chemicals for plant protection resulting in large-scale and long-term adverse impacts on environment and economy.

Biologically and economically sustainable agro-ecosystems must be based on ecological principles [12-15]. A commercial farm is considered as an integral ecosystem, where each change affects a complex of interrelationships. For example, a high content of soil nitrates can stimulate a strong development of weeds and cause nitrate pollution of groundwater. Cultivation of crops that consume nitrogen prevents its washing out and contributes to a better balance of nutrients thus avoiding the problem [13]. Genetic and species diversity is achieved through i) a wide range of crops in crop rotations, ii) preservation of natural environment areas as habitats of natural enemies of pests, and iii) adjustment of livestock population concordantly to capability of field crop cultivation. Crop and livestock diversity also contributes to sustainable farming when market fluctuations. In natural ecosystems, green plants, due to photosynthesis, insects, herbivorous animals and predators, and microorganisms can constantly synthetize, decompose and use nutrients. Agro-ecological farming cannot fully be the same as natural substance turnover but can simulate it. So, all products of vital activity of the agro-ecosystem are subject to utilization. Among other benefits, this makes it possible to minimize purchases for the needs of the farm.

No need to stress that organic agriculture basically goes for soil building. As soil fertility is cornerstone for ecological farming, an increase in yielding must be in compliance with careful use of natural resources (soil, water, air, forests, biodiversity). Organic fertilizers and residues, when involved in recycling, improve soil properties, and soil microfauna and flora promote the weathering of rocks and release important elements that are absorbed by plants and eventually incorporated into the ecosystem of the soil. Thus, crop production is associated with soil fertility restoration, food and feed production, and the maintenance of chemical element circulation in a soil-plant-animal system.

Main elements of commercial farming. Back in the XVIIIXX centuries, Russian and Soviet scientists noted [16, 17] that it is the linkage of plant growing and livestock that is crucial for optimal eco-farming. Manure and slurry compensate removal of $\mathrm{N}$ and other chemical elements with plant biomass [18], thus improving soil fertility and allowing to control over the agroecosystem. Therefore, the farm should cultivate both food and fodder crops, considering also which plants are dependent on organic fertilizers, and which are independent and perform the soil-improving function. For this, the soils are examined for suitability for certain cultivars. Legumes are the most important source of nitrogen and a factor in increasing soil fertility. The cultivation of nitrogen-fixing legumes in large areas also provides the livestock with high-protein fodder.

Hence, ruminants, eating post-harvest residues and giving valuable manure, are the main in animal husbandry under organic farming. In stall maintenance, biological features of breeds should be considered. Animal breeding necessitate special attention. Pigs and poultry livestock must be limited to not compete with other species and humans for fodder and territory. Manure can be produced both for own needs and for sale. Agrochemically, the function of animal husbandry is nitrogen recycling. 
Crop rotation. Plants are the main sources of energy for the whole soil ecosystem. Flora along with soil microfauna contribute to the weathering of rocks and the release of minerals, which in turn are absorbed by plants and incorporated into soil ecosystems.

Nowadays, crop production is mainly estimated by quantitative indicators. This makes species composition of cultivated plants poorer, and low-field crop rotations (unlike multipole ones) do not provide a natural restoration of soil fertility [19-21], which is replenished by mineral fertilizers.

In eco-farming, crop rotations perform several functions [16, 22, 23]. The use of legumes provides the agro-ecosystem with nitrogen and fodder for livestock. Using different crops prevents the unrestricted reproduction of pests and pathogens, and also restrains the development of each species of weeds below a dangerous level due to the alternation of spring and winter crops (including late and early ripening varieties), crops that deplete and enrich the soils (some crops are more 'giving', others take more than the give), and the use of perennial seeded meadows.

The art of farming is to orchestrate all particular crops and animals in such a way, in space and time, that the overall effect benefits the soil fertility and human nutrition. Crop rotation (temporal variation) and mixed cropping (spatial variation) and mixed farming (plant and animal production) are tools thereto, which are particularly well developed in organic agriculture (agroecology, permaculture, biodynamics).

The soil in one rotation is equal in fertility. Crop rotation should be multifield, including at least two fields of perennial grasses (legumes and their mixtures with cereals), and involve different plant species. Legumes in the crop rotation are up to $25-33 \%$. One year the fields are leaving fallow with annual forage grasses or used for fodder crops that provides weed control. The use of intermediate and subcultivated crops (beans) as often as possible is beneficial. Intermediate cultures as siderates inhibit the weed growth. In the Non-chernozem zone, the cultivation of intermediate crops has advantages [22-25]. Organic fertilizers are advisable to apply under the fallow culture and the crop used before sowing or planting tilled crops. Interval between cultures that consume soil nitrogen and legumes or crops treated with organic fertilizers should be no more than 2 years. Plants with a long early stage of development are included in the crop rotation after herbages that suppress weeds.

So for example a soil friendly crop rotation of $3 / 7$ in wheat (bread and fallow), $1 / 7$ in oil crops, $1 / 7$ in potatoes, beetroots and vegetables and $2 / 7$ in pulses and fodder grains would facilitate a European nutrition pattern on an on-farm fixed $\mathrm{N}$ ration [26].

Use of manure and slurry. These are the main organic fertilizers, but in uncontrolled application manure and slurry, like chemical fertilizers, adversely affect the environment $[11,18]$. Critical processes in the nutrient cycling in the agro-ecosystem, especially nitrogen volatilization and leaching, attract special attention.

To avoid high nitrogen input to soil when using liquid excretions of animals and manure contamination, it is necessary to control the ratio of carbon and nitrogen in feeds (along with the amount of protein and exchange energy). In using straw as litters, its absorption capacity, porosity, ease replacement and good biodegradability is important (that is why the $\mathrm{C}: \mathrm{N}$ ratio is important too). At storing, care should be taken to trap seepage slurry to use nitrogen and potassium in recycling (specific use). Storage should provide repeated absorption of nitrogen mineralized by microorganisms, and its inclusion in compostable sources of carbon and energy (straw, etc.). Straw of cereals and decompos- 
able hollow stems of other plants, when added to solid and liquid manure, prevents nitrogen volatilization. Technical utilization of manure and slurry (filtration, drying, etc.) is energy-intensive, requires time and resources, including labor, and is not in line with the bioecological concept. In the Netherlands, cattle of a live weight of $490-500 \mathrm{~kg}$ produces on average about $12-15$ tons of manure (litter with urine) per year, where the organic matter is $20-22 \%$ and nitrogen is $0.7-0.8 \%[11,26]$.

Organic agriculture and human health. A recent meta analysis [27] of 343 previous studies find organic milk and meat to contain ca $50 \%$ more beneficial omega-3 fatty acids than non-organic. This also applies to organic dairy like butter, cream, cheese and yoghurt. Thus they appear to be nutritionally superior to the dairy from conventional agriculture. Further key findings are the follows. Organic meat had slightly lower concentrations of two saturated fats linked to heart disease; organic milk and dairy contains $40 \%$ more conjugated linoleic acid (CLA) (CLA has been linked to a range of health benefits including reduced risk of cardiovascular disease, certain cancers and obesity, but evidence is mainly from animal studies) [27]. Organic milk and dairy contains slightly higher concentrations of iron, Vitamin E and some carotenoids. Organic milk contains less iodine than non-organic milk (an issue which organic farmers have started to address with mineral supplements).

Another survey states [28] that the benefits of organic products are higher levels of vitamin $\mathrm{C}$, iron, magnesium, and phosphorous than nonorganic foods of the same type; higher levels of antioxidants, naturally occurring compounds associated with a reduced risk of chronic diseases and certain cancers; fewer toxic chemicals such as nitrates and pesticide residues; no genetically modified organisms (GMOs).

Organic food is especially recommended for vulnerable consumers, like children and pregnant woman,

Agro-ecology. In 2015 FAO's Deputy Director-General Maria Helena Semedo warns that agriculture is discovered as a big threat in the fight against climate change [29]. She calls upon governments to integrate this sector into their urgent climate policies. If fail to do so, for example because they see it as a threat for standing positions, she predicts ever more hungry people in the world. Agriculture and the good, carbon enriching use of soils, thus have made a strong debut to the series of measures against greenhouse gases, the sources of global warming. From the 186 countries that have already laid out voluntary plans to reduce their emissions, around 100 of them include measures related to the use of soils and agriculture. But M.H. Semedo warns that those measures must be effectively implemented, not stay paper on shelves.

A recent meta-analyses on the productivity of organic versus non-organic agriculture states that, with appropriate crop rotations and multi-cropping systems, organic (soil building) agriculture produces only $8-10 \%$ less as compared to non-organic (soil eroding) agriculture [30]. Moreover, the various types of organic agriculture all contribute, in one way or another, to a striking decrease of the externalised problems that conventional agriculture confronts society with, now and in the future. So for example, besides the soil erosion and land degradation, there is the loss of biodiversity, the eutrophication and oceanic dead zones, the pesticide effects on humans, environment and wildlife, the greenhouse gas emissions, and the regime shifts in hydrological cycling (drought). All this multiplies when forestry effects are included in (added to) those of agriculture.

Solving the global hunger problem - can organic agriculture feed the world? In today's world, there is a double problem - hunger and obesity as consequences of poverty. At present, the world production of 
high-calorie products exceeds the needs of mankind, but social, political and economic factors limit its fair distribution, as well as the consumption of healthy food [31]. The latter stands for over $100 \mathrm{~kg} / \mathrm{pp}$ in the NW countries and some $10 \mathrm{~kg} / \mathrm{pp}$ in poor countries [32]. Only increasing yields will not solve these problems - it is obvious that it is necessary to reduce the difference in profitability between sustainable and traditional agriculture.

Therefore multiple food systems must be combined to improve resilience through enhanced diversity, and different forms of farming must be allowed to coexist, each fulfilling a different function. The example of Brazil shows how this can be fairly well and multi beneficially realised [33]. In opinion of B. Halweil (personal communications), looking at 77 studies from the temperate areas and tropics, the Michigan team found that greater use of nitrogen-fixing crops in the world's major agricultural regions could result in 58 million metric tons more nitrogen than the amount of synthetic nitrogen currently used every year. Research at the Rodale Institute in Pennsylvania showed that red clover used as a winter cover in an oat/wheat-corn-soy rotation, with no additional fertilizer inputs, achieved yields comparable to those in conventional control fields [33]. Even in arid and semi-arid tropical regions like East Africa, where water availability is limited between periods of crop production, drought-resistant green manures such as pigeon peas or groundnuts could be used to fix nitrogen [33]. In Kenya, farmers using leguminous tree crops have doubled or tripled corn yields as well as suppressing certain stubborn weeds and generating additional animal fodder [33].

Integrated agriculture as an alternative. Many farmers and some scientists do not agree that one can do without using chemicals. The concept of integrated agriculture is based on the fact that such measures should be used as rarely as possible and only in necessary cases, or biological preparations that are available to farmers should be applied [11,34]. However, the widespread introduction of integrated agriculture will not solve the pressing problems of agricultural production. Chemicals for plant protection always violate the ecological balance (in recent years, the use of fungicides in the West has led to the widespread spread of the yellow dwarf barley virus, etc.), their use is associated with an increase in the toxicological and ecotoxicological risk to the environment and human health. Because of introduced mineral fertilizers, the content of nitrates in groundwater is constantly growing, and the soil is oversaturated with nitrogen and phosphorus. In ecological farming, when the livestock population correlates with the farm land area (no more than two animals per hectare), purchases of feed are greatly reduced and the introduction of mineral nitrogen fertilizers is prohibited, the problem intersects in its root. That is, addressing the problems of environmental pollution in the concept of integrated agriculture seems less effective.

Prospects for eco-agriculture. Because of the urgent need to eliminate overproduced food stuff in EU, for the first time in 1989, the program of ecological farming in the framework of extensification was financially supported, which increased the status of organic farming [35].

By 2020, the world market for organic products is projected to be 200250 billion dollars, with the potential of the Russian market of 700 billion rubles, i.e. Russia can account for 10-15\% of the market [6]. In case of the development of organic farming, 1 million new highly paid workplaces will be created in the agroindustrial complex of Russia. Examples of regions for cultivation of ecologically clean products are Transbaikalia (the Baikal Lake protection law is effective there and any application of toxic chemicals is prohibited), and the Republic of Crimea. Because of extension of its territory and infrastructure problems, it is expedient to launch a closed cycle of organic production in the Far East [6]. Generally, organic farming shows its worth in areas where high farming 
techniques are inconsistent. In Russia, there is a potentially high demand for organic food, and the current biotechnologies make it possible to move towards organic farming techniques for many crops without detriment to yields and increase in costs. Finally, this is not only healthy and nutrient-enriched food, but also the preservation of habitats, and caring attitude towards wild and agricultural animals.

So, traditional industrial agriculture provide large volumes of world production, but lead to land degradation, water resources and ecosystems, greenhouse gas emissions, and reduce biodiversity. At the same time, quality and nutritional value of products decreases, which causes obesity and an increase in food-related diseases. Precision technologies can improve some indicators of agriculture but do not provide long-term prospects. A fundamentally different model is based on the diversification of farms and agricultural landscapes, the stimulation of biodiversity and the interaction between different species. Such a model is part of the strategy for the formation of long-term fertility, healthy agro-ecosystems and the sustainable existence of mankind. Diversified agroecological systems are able to compete with industrial (traditional) agriculture for overall productivity (especially under environmental stress) and provide a greater variety of food nutrients that will improve the health of the population.

\section{REFERENCES}

1. Van Mansvel't Ya.D., My u ld e r Dzh. Agrarnaya nauka, 1994, 4: 22-24 (in Russ.).

2. Van Mansvelt J.D., van de r Lubbe M.J. Checklist for sustainable landscape management. Elsevier, 1999.

3. Van Mansvelt J.D. Methodische Aspekte Der Alternativen Landwirtschaft. In: Ökologie und Landwirtschaft. Eine Losung für die Zukunft? Stiftung Ökologischer Landbau. Hartmann, Kiel, BRD, 1984: 51-76.

4. Van Mansvel't Ya.D., Te mirbekova S.K. Materialy Mezhdunarodnoi nauchnoprakticheskoi konferentsii «Fundamental'nye i prikladnye issledovaniya v bioorganicheskom sel'skom khozyaistve Rossii, SNG i ES» (9-12 avgusta 2016 goda), tom 1 [Proc. Int. Conf. «Fundamentals and practical study in bioorganic agriculture in Russia, CIS and EC». August 9-12, 2016)]. Moscow, 2016, V. 1: 250-263 (in Russ.).

5. Temirbekova S.K., Molchan J.M., Van Mansvelt J.D., Gareev R.G., Gotovseva I.P., Musinov K.M., D rozdovskay a A.A. Organic agriculture: adaptability, immunity, plant breeding: Rudolf Steiners «Course on agriculture» - 80-year anniversary. Moscow-Astana, 2005 (ISBN 9965-725-7-6).

6. Z e 1 i n s k a y a V.I. Agrarnoe obozrenie, 2014, 5: 18-22 (in Russ.).

7. Se me nov A.M., G li nus h k in A.P., S o k o lov M.S. Materialy Mezhdunarodnoi nauchnoprakticheskoi konferentsii «Sovremennye problemy gerbologii $i$ ozdorovleniya pochv» (21-23 iyunya 2016 goda) [Proc. Int. Conf. «Relevant problems of garbology and soil health» (June 21-23, 2016)]. Bol'shie Vyazemy, 2016: 283-291 (in Russ.).

8. Semenov A.M., S e me nov V.M., Van B rugge n A.Kh.K. Agrokhimiya, 2011, 12: 420 (in Russ.).

9. D o r a n J.W., Z e is s M.R. Soil health and sustainability: managing the biotic component of soil quality. Appl. Soil Ecol., 2000, 15: 3-11.

10. S e m e n o v A.M., S o k o lov M.S. Agrokhimiya, 2016, 1: 3-16 (in Russ.).

11. Va n B rugge $\mathrm{n}$ A.H.C., S e m e nov A.M. Soil health and soilborne diseases in organic agriculture. In: Plant diseases and their management in organic agriculture. M.R. Finckh, A.H.C. van Fruggen, L. Tamm (eds.). APS PRESS, 2015.

12. S a r a n i n E.K., N e s t e rov a A.V. V sbornike: Bolotovskie chteniya 1997, 1998 i 1999 godov [In: Bolotov Readings 1997-1999. A.A. Zhuchenko (ed.)]. Moscow, 2000: 44-45 (in Russ.).

13. Zhuchenko A.A. Strategiya adaptivnoi intensifikatsii sel'skogo khozyaistva (kontseptsiya) [Strategy for adaptive intensification in agriculture: a concept]. Pushchino, 1994 (in Russ.).

14. Z hu c he nko A.A. Ekologo-geneticheskie osnovy prodovol'stvennoi bezopasnosti Rossii [Ecogenetic fundamentals of food security in Russia]. Moscow, 2008 (in Russ.).

15. $\mathrm{Zhu} \mathrm{ch}$ e $\mathrm{k}$ o A.A. Adaptivnoe rastenievodstvo (ekologo-geneticheskie osnovy). Teoriya i praktika. Tom II [Adaptive plant growing - ecogenetic bases. Fundamental and practical aspects. V. II]. Moscow, 2009 (in Russ.).

16. Vil'y a ms V.R. Zemledelie s osnovami pochvovedeniya [Agriculture with the fundamentals of soil science]. Moscow, 1939 (in Russ.). 
17. B o lo to v A.T. Izbrannye trudy [Selected works]. Moscow, 1988 (in Russ.).

18. Top 10 Composting Techniques. Available http://www.compostjunkie.com/compostingtechniques.html. Accessed June 05, 2017.

19. Z h u c h e $\mathrm{nk}$ o A.A. Adaptivnaya strategiya ustoichivogo razvitiya sel'skogo khozyaistva Rossii $v$ XXI stoletii. Teoriya i praktika. Tom I [Adaptive strategy of agriculture development in Russia for XXI. Fundamentals and practical aspects. V. I]. Moscow, 2011 (in Russ.).

20. $\mathrm{Z}$ h u c h e $\mathrm{nk}$ o A.A. Puti innovatsionno-adaptivnogo razvitiya APK Rossii v XXI stoletii [Innovative and adaptive development of Russian agriculture for XXI]. Kirov, 2011 (in Russ.).

21. Z h u c h e $\mathrm{n}$ k o A.A. Obespechenie prodovol'stvennoi bezopasnosti Rossii $v$ XXI veke na osnove adaptivnoi strategii ustoichivogo razvitiya APK (teoriya i praktika) [Food security in Russia for XXI, as based on adaptive strategy of sustainable development of agriculture: theoretical bases and practice]. Kirov, 2009 (in Russ.).

22. L o s h a k o v V.G. Agrarnaya nauka, 1994, 6: 24-26 (in Russ.).

23. L o s h a k o v V.G. Materialy Mezhdunarodnoi nauchno-prakticheskoi konferentsii «Fundamental'nye $i$ prikladnye issledovaniya v bioorganicheskom sel'skom khozyaistve Rossii, SNG i ES» (9-12 avgusta 2016 goda), tom 2 [Proc. Int. Conf. «Fundamentals and practical study in bioorganic agriculture in Russia, CIS and EC». August 9-12, 2016)]. Moscow, 2016, V. 2: 203-222 (in Russ.).

24. Loshakov V.G. Sevooborot $i$ plodorodie pochvy [Crop rotation and soil productivity. V.G. Sychev (ed.)]. Moscow, 2012 (in Russ.).

25. L o s h a k o v V.G. Promezhutochnye kul'tury $v$ sevooborotakh Nechernozemnoi zony [Intermediate crops for crop rotations in Russian Nechernozemie]. Moscow, 1980 (in Russ.).

26. O o m e n G.J.M. Nitrogen cycling and nitrogen dynamics in ecological agriculture. Biological Agriculture and Horticulture, 1995, 11(1-4): 181-192.

27. Średnicka-Tober D., B arański M., S e a l C., S anderson R., Be nbrook C., Steinsham n H., Gromadzka-Ostrowska J., Rembiałkowska E., Skwarło-S ońt a K., Eyre M., Cozzi G., Larsen M.K., Jordon T., Niggli U., Sakowski T., Calder P.C., Burdge G.C., Sotiraki S., Stefanakis A., Yolcu H., Stergiadis S., Chatzidimitriou E., Butler G., Stewart G., Lei f e r t C. Composition differences between organic and conventional meat; a systematic literature review and meta-analysis. Brit. J. Nutr., 2016, 115(6): 994-1011 (doi: 10.1017/S0007114515005073).

28. De Schutte $\mathrm{r}$ O. Report of the special rapporteur on the right to food. Available http://www2.ohchr.org/english/issues/food/docs/A-HRC-16-49.pdf. Accessed June 05, 2017.

29. S e m e d o M.H. Agriculture should be integrated in climate change policies. Available http://www.fao.org/members-gateway/news/detail/en/c/357972/._Accessed June 05, 2017.

30. Ponisio L.C., M'Gonigle L.K., Mace K.C., Palomino J., de Valpine P., $\mathrm{Kremen}$ C. Diversification practices reduce organic to conventional yield gap. Proc. Biol. Sci., 2014, 282(1799): 20141396 (doi: 10.1098/rspb.2014.1396).

31. Waste and spoilage in the food chain. Decision Intelligence Document. The Rockefeller Foundation, 2013. Available https://assets.rockefellerfoundation.org/app/uploads/20130528220516/Waste-and-Spoilagein-the-Food-Chain.pdf. Accessed June 05, 2017.

32. Gustavsson J., Cederberg C., Sonesson U., van Otterdijk R., Meybeck A. Global food losses and food waste - Extent, causes and prevention. FAO, Rome, 2011.

33. Philpott T. Organic farming just as productive as conventional, and better at building soil, Rodale finds. March 26. 2011. Available http://grist.org/article/2011-03-25-rodale-data-showorganic-just-as-productive-better-at-building/. Accessed June 05, 2017.

34. Mo nast y rs k i i O.A. Materialy Mezhdunarodnoi nauchno-prakticheskoi konferentsii «Sovremennye problemy gerbologii $i$ ozdorovleniya pochv» (21-23 iyunya 2016 goda) [Proc. Int. Conf. «Relevant problems of garbology and soil health»(June 21-23, 2016)]. Bol'shie Vyazemy, 2016: 280-283 (in Russ.).

35. V a n M a n s velt J.D., Z n a o D. Checklist for sustainable landscape management. Elsevier, 1999: 41-84. 